\title{
BUCOVINA (ROMANIA) - A MODEL OF ETHNIC AND RELIGIOUS COHABITATION BETWEEN EAST AND WEST
}

DOI: http://dx.doi.org/10.18509/GBP.2016.39

UDC: $2-673.5(478)$

\author{
Prof. Dr. Vasile Efros ${ }^{1}$ \\ Prof. Dr. Gheorghe Romanescu ${ }^{2}$ \\ ${ }^{1}$ Stefan cel Mare University of Suceava, Faculty of History and Geography, Department of \\ Geography, Universitatii 1, Suceava, Romania \\ ${ }^{2}$ Alexandru Ioan Cuza University of Iasi, Faculty of Geography and Geology, Department of \\ Geography, Iasi, Romania
}

\begin{abstract}
Bucovina is a part of the Moldavian Principality, which is now a unique region of multiethnic cohabitation situated "between East and West". From a geographic point of view, Bucovina belongs to the eastern part of Europe. From a geopolitical point of view, Bucovina played for a long time the role of a region situated at the crossroads of the influence areas of the Austrian, Russian and Ottoman Empire. Ethnically speaking, it was substantially modified because of the influences in time of the German and Jewish Kulturträger who spoke German or Yiddish in the period 1775-1918, of the Slav and Soviet in the post-war period. Nowadays, the Historical province Bucovina is divided into two parts: the southern part occupies an important part of Suceava County (Romania), and the northern part belongs to the present Czernowitz region from Ukraine. As a consequence of the cultural, political and economic development, the south of Bucovina is currently inhabited by Romanians, Ukrainians, Polish, Ruthenians, Hutsuls and gypsies, their number changing depending on the historical period and the influences of the geographic position.
\end{abstract}

Keywords: Bucovina, demography, religion, ethnic structure.

\section{INTRODUCTION}

The territory of present day Bucovina was, before the year 1774, an integral part of the Principality of Moldavia, a state which existed in Eastern Europe for almost five centuries. A toponym of Slavic origins, Bucovina (Beech country) was attested for the first time, in a document issued by the princely office of Moldavia, during the reign of Roman I, on the 30th of March 1392. In the year 1775, this region of the Moldavian state was annexed by the Habsburg Empire and with it, also its name, which had the same meaning: Buchenland. From a juridical point of view the region became an Austrian province. In the year 1918, Bucovina splits from Austria and reunites with the Kingdom of Romania, in its historical borders. In summary, Bucovina's situation can be reproduced as follows:

-1359-1775 - Integral part of the Principality of Moldavia;

-775-1918 - Integral part of the Habsburg Empire;

-1918-1940 and 1941-1944 - Integral part of the Kingdom of Romania;

-1940-1941 and 1944-1991 - the northern part of the region is occupied by the USSR with the southern part remaining in the borders of Romania. 
-After 1991, northern Bucovina, occupied by the USSR, remains a component part of the Czernowitz region of Ukraine.

The special history and the geographical location of Bucovina, has determined a peaceful coexistence between a great number of different ethnic minorities, Bucovina itself being considered a region of cultural interactions, situated "Between the Orient and the West" [1], an expression publicized by the renowned German scientist Erich Beck (1963) [2].

\section{GEOGRAPHICAL LOCATION}

After the occupation of Bucovina by the Habsburgs, Moldavia loses its borders with Poland. Now Bucovina had clear and precise borders; borders which would be ratified only in 1887 (Fig. 1). Bucovina was presented as Austrian territory, the northernmost point being the turning of the Dnister river, near Repujinet commune and the southernmost being the tip of the Red Stones Mountain near Dorna Candrenilor commune. In the east, it stretched to the mouth of the Racova stream, which flows into Suceava River near Chiliseni, while in the west it went all the way to the bend of the Ceremus river, south of the Iablonita commune. Thus, the borders of Bucovina are formed in the North by the Dnister River, starting from Babin commune and all the way to the point in which it joins with Black Creek. In the East they are formed by the jonction of the Rachitna stream with the Prut river, near Noua Sulita, the very same point also marking the borders between Bucovina, Russia and Romania. The rest of the border which separates Bucovina from the Kingdom of Romania is formed by the river Prut, Lucavita stream and then by Molnita stream until the latter's junction with Siret river, Rusterba creek an finally with Suceava river.

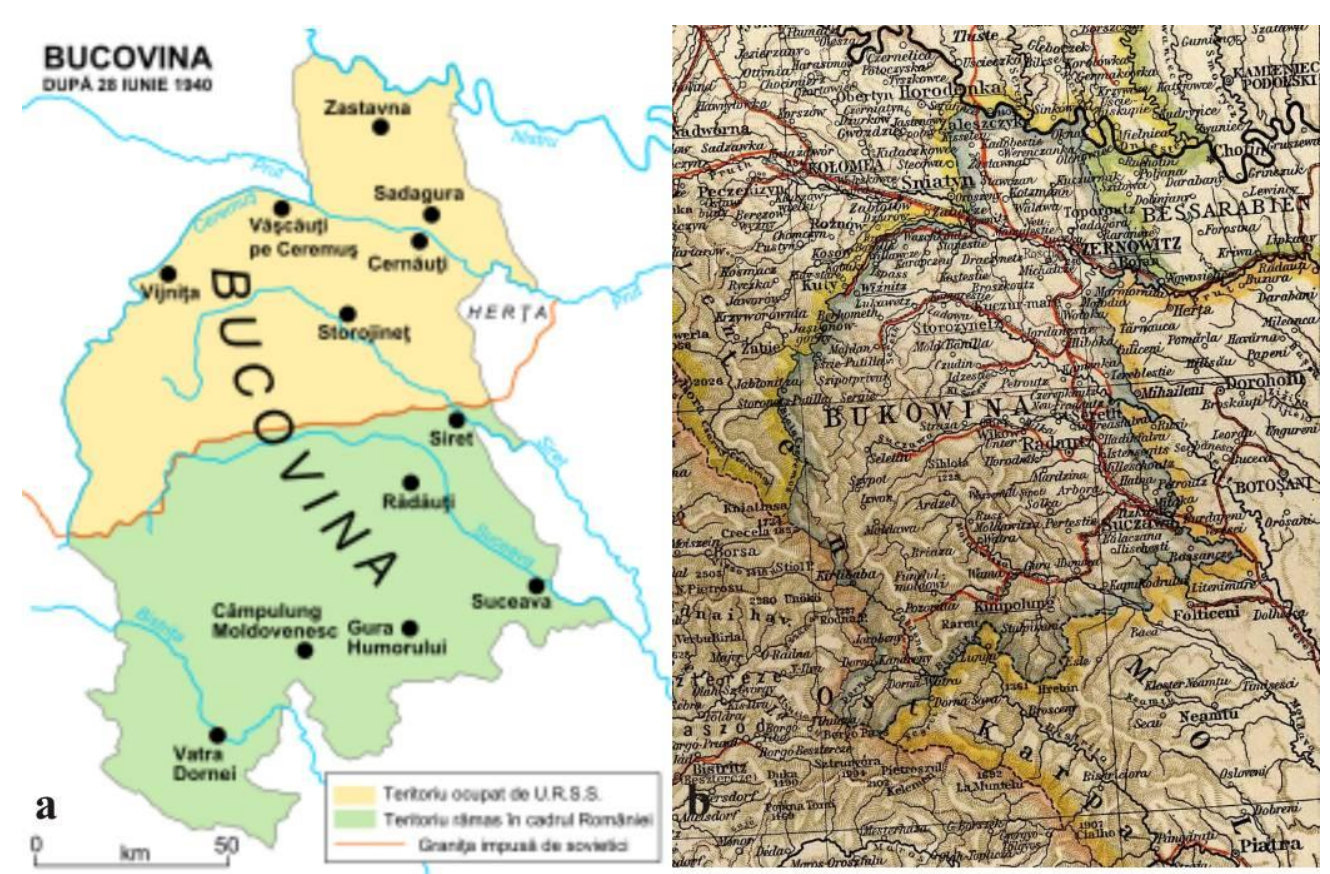

Figure 1. Bucovina after the year 1940 and the geographical position of historic Bucovina

In the south, the border with Romania is formed by the Racova, Somuzul Mare, Somuzul Mic, Hranita and Saca creeks, by the mountains peak of Obcina Isaccii, Baiesescul, Grebenul and Obcina Chiril, then by the Bistrita river, until its junction with Black Creek, 
the tributary Sarisor and Obcina Vanatorului. From this point on, Bucovina's western border begins: the top of the Red Stones mountain, which constitutes the border between Bucovina, Romania and Transylvania. From here, the border towards Transylvania is formed by the Tesna Imputita, Cosna and Deaca creeks, and Bistrita Aurie river. Then, near Carlibaba commune, the border reaches the point of separation between Bucovina, Transylvania and Hungary. The border with Hungary is formed by the Tibaului river, all the way to the foot of Sarata were we find another point of separation, this time between Bucovina, Hungary and Galicia. Further east, the border is formed by the Parcalab creek and the waters of Ceremus river until its junction with the Prut; then by the Prut itself, and then Turetchi creek, all the way to the Dnister, near Babin commune [3].

\section{MATERIALS AND METHODS}

The specialty literature (human geography, demography, theology, history, economy etc...), dealing with Bucovina is extremely rich, because it makes a special reference on that which is called a multiethnic, multicultural and multiconfessional convergence. Many of the materials regarding Bucovina's history, regarding the demographic and confessional characteristics have been taken from the speciality literature, from census and from the field. On top of that, documents from the State Archive of Czernowitz Region and the Suceava National Archives have also been consulted. Field research has been limited to the gathering of statistic data. The whole activity took place during the summer of 2015.

\section{RESULTS}

The explanations for the evolution of geo-demographic and ethnical changes of the population between the years 1775 - 1918, can be found in a relatively large number of publications, the data presented there, being as usual, just estimates. The ethnical structure of the population of Bucovina was in a permanent process of modification, depending on the historical period in which the province found itself. In this context we will analyze the modifications in question on certain historical periods, because of the different geopolitical, economical and social circumstances.

Until the annexation of Bucovina in 1774, the population was mostly Romanian [4], the author, invoking the fact that Austria did not cite as a reason for annexation the national character of the territory, which would have been different from the rest of Moldavia. In the period of time just prior to the annexation of Bucovina to the Habsburg Empire, the population was sparse, and the census taken between the years $1772-1773$ by Rimsky Korsakov notes a figure of 84.514 people which were assigned in 266 settlements and three market towns. From an ethnical standpoint, the population structure presented itself like this: Romanians $-64,23 \%$, Ruthenians $-20,26 \%$, Hutsuls $-7,06 \%$, Gypsies $-3,14 \%$, Jews $-2,86 \%$, Russians $-0,54 \%$, Polish and Germans.

For these reasons, the population number in Bucovina at the beginning of the Habsburg dominance is very differently evaluated by the scientists and varies from 11,421 families for the year 1774 [5] to 17,047 families for the years 1775-1776 [6]. For an objective evaluation of the character of the ethno-confessional changes during the period which follows, the necessity of a reference point becomes obvious. In this sense, as a reference point we can consider the population census, taken in the second half of 1774 and in the first months of 1775. According to this census, in Bucovina, there were 290 settlements 
with 62 hamlets, in which there lived 17,047 families or around 85,000 people [6]. According to the same sources, we can even invoke a certain ethnic structure, because the statistical data presented here, also refer to the other ethnic groups inhabiting the province: 58 Armenians, 526 Jews and 294 nomadic gypsies. It's much more difficult to establish however, the true number of the Slavic population in the territory.

Therefore Klun (1876) [7] claimed that at the beginning of the Austrian colonization, in Bucovina there were some 50,000 Romanians and around 20,000 Ruthenians. Mikulicz (1878) observed that "at the moment of the union with Austria, there were in Bucovina 75 thousand people... The main base of the region's population were 55 thousand Romanians and 12 thousand Ruthenians; outside of these, there lived, dispersed among various settlements around 8 thousand people of other nationalities, mostly Jews, Armenians, gypsies and in three cities a few Germans". According to Werenka (1895) [8] in 1774, all across Bucovina's territory, there were three cities and 330 villages, in which there lived 12,443 families or around 62,2015 people, and Joseph Rohrer (1804) claimed that "when Austria occupied Bucovina, the population in those first years was around 11-12 thousand families".

According to Roman (1995) [9] the population in 1774 was around $146,000-149,000$ people, the Romanians representing $86-69 \%$ or 124,910 people (Table 1). The comparative analysis of the diverse number of sources relating to the number of people living in Bucovina before the beginning of the Habsburg administration makes us conclude that the number was between 56,000 - 85,000 [10] and 67,000-73,000 [4].

Table 1 National composition of Bucovina in 1774

\begin{tabular}{|l|c|c|c|c|c|c|c|c|}
\hline Total & Romanians & Ruthenians & Hutsuls & Russians & Jews & Gypsies & Armenians & Others \\
\hline 68704 & 40924 & 15690 & 5715 & 1405 & 2375 & 2100 & 275 & 220 \\
\hline $\mathbf{1 0 0 \%}$ & $\mathbf{5 9 . 5 6}$ & $\mathbf{2 2 . 8 4}$ & $\mathbf{8 . 3 2}$ & $\mathbf{2 . 0 4}$ & $\mathbf{3 . 4 6}$ & $\mathbf{3 . 0 6}$ & $\mathbf{0 . 4}$ & $\mathbf{0 . 3 2}$ \\
\hline
\end{tabular}

Source: Data compiled on basis of the anthroponomical analysis of the Russian census [4].

From a confessional standpoint, at the beginning of the Austrian domination, the majority of the population was orthodox. Both the Romanian majority and other national minorities were part of it, such as the Ukrainians (Ruthenians and Hutsuls), the sedentary and nomadic gypsies and the Armenian community. Alongside the orthodox, a significant part was constituted by the mosaic minority, which in 1774 represented around $3-3.5 \%$ [4]. Only a few German and Polish families were catholic or protestant.

In the following period, the population of Bucovina greatly increases, even explosively so, following the massive colonization program organized by the Austrian authorities, particularly on economic grounds; the living conditions here being much more favourable than in the neighbouring regions. Thus, in 1869, Bucovina's population reaches 511,964 people [11], the last census from 1910 providing 798,355 people, and the ethnic structure presents itself like so(Table 2) [12]:

Table 2 National composition of Bucovina in 1910

\begin{tabular}{|c|c|c|c|c|c|c|}
\hline Total & Romanians & Ruthenians & Germans & Jews & Polish & Others \\
\hline 798,355 & 273,354 & 305,101 & 73,073 & 95,778 & 36,211 & 14,838 \\
\hline $\mathbf{1 0 0 \%}$ & $\mathbf{3 4 . 2 4}$ & $\mathbf{3 8 . 2 2}$ & $\mathbf{9 . 1 5}$ & $\mathbf{1 2 . 0 0}$ & $\mathbf{4 . 5 4}$ & $\mathbf{1 . 8 5}$ \\
\hline
\end{tabular}

From a geographical point of view, the distribution of the two largest communities, the Romanians and the Ruthenians was thus: the Ukrainians were the majority in the northern 
side of Bucovina, and the Romanians in the south of it. The Germans and Jews lived mainly in urban environments.

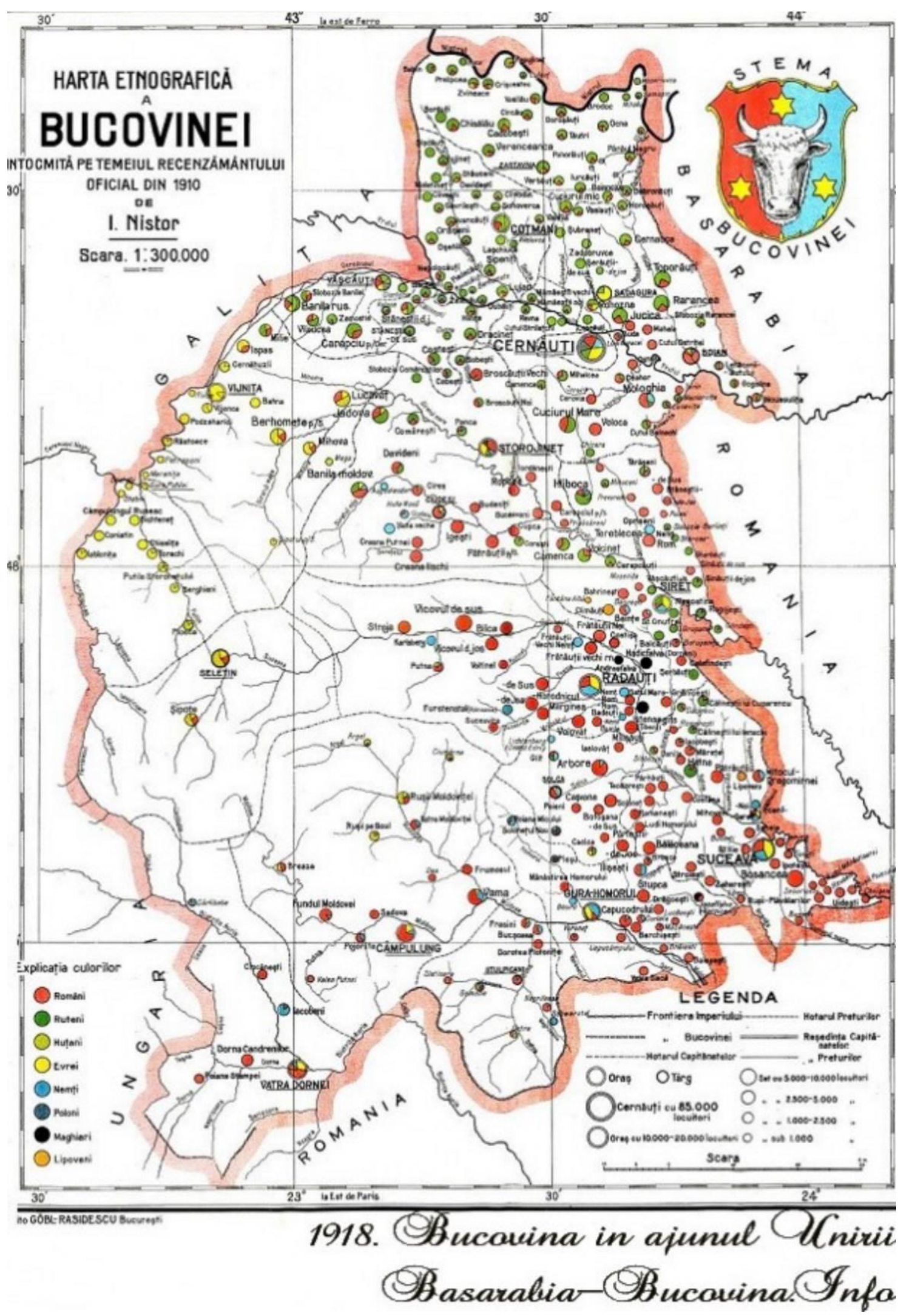

Figure 2. The ethnographic map of Bucovina (author I. Nistor) 


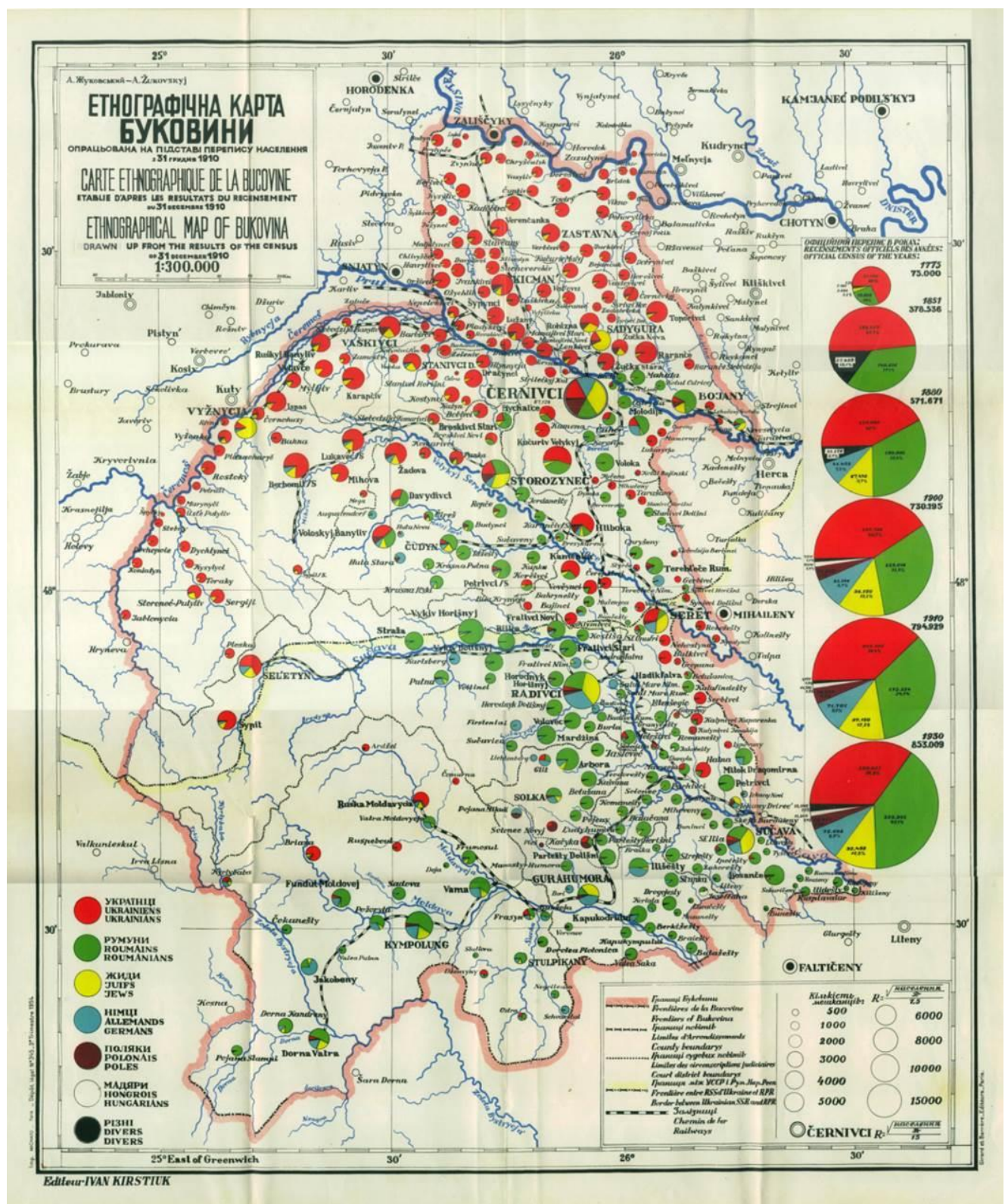

Figure 3. The ethnographic map of Bucovin (author A. Zukovski)

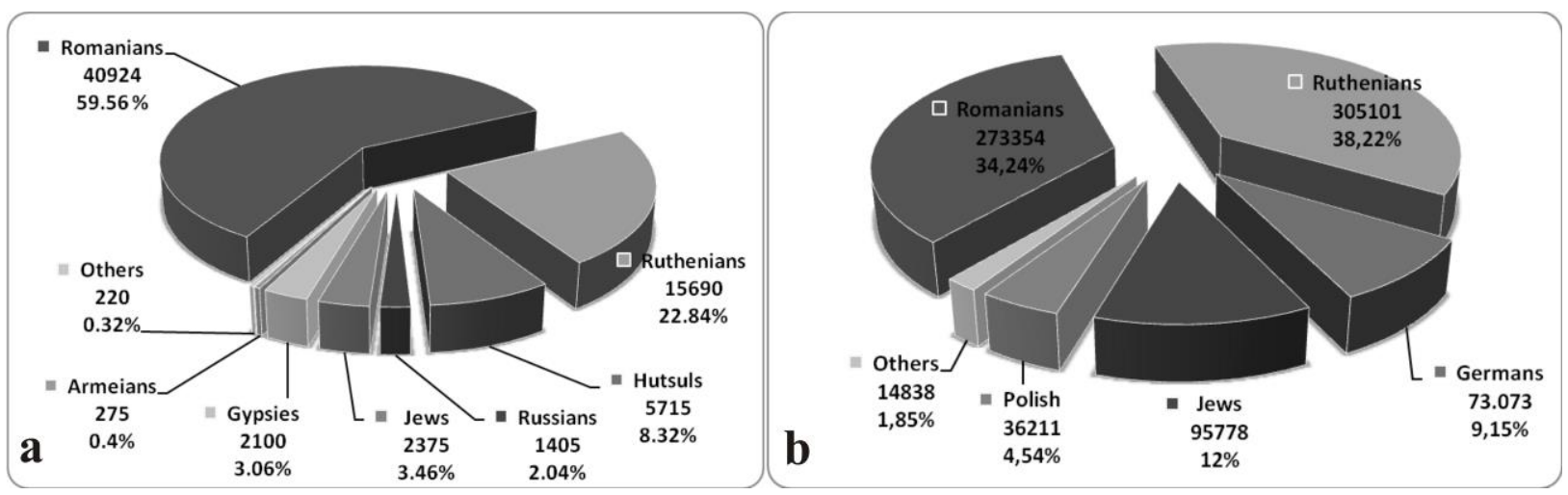

Figure 4. The national structure of population in Bucovina in 1774 and the national structure of population in Bucovina in 1910 


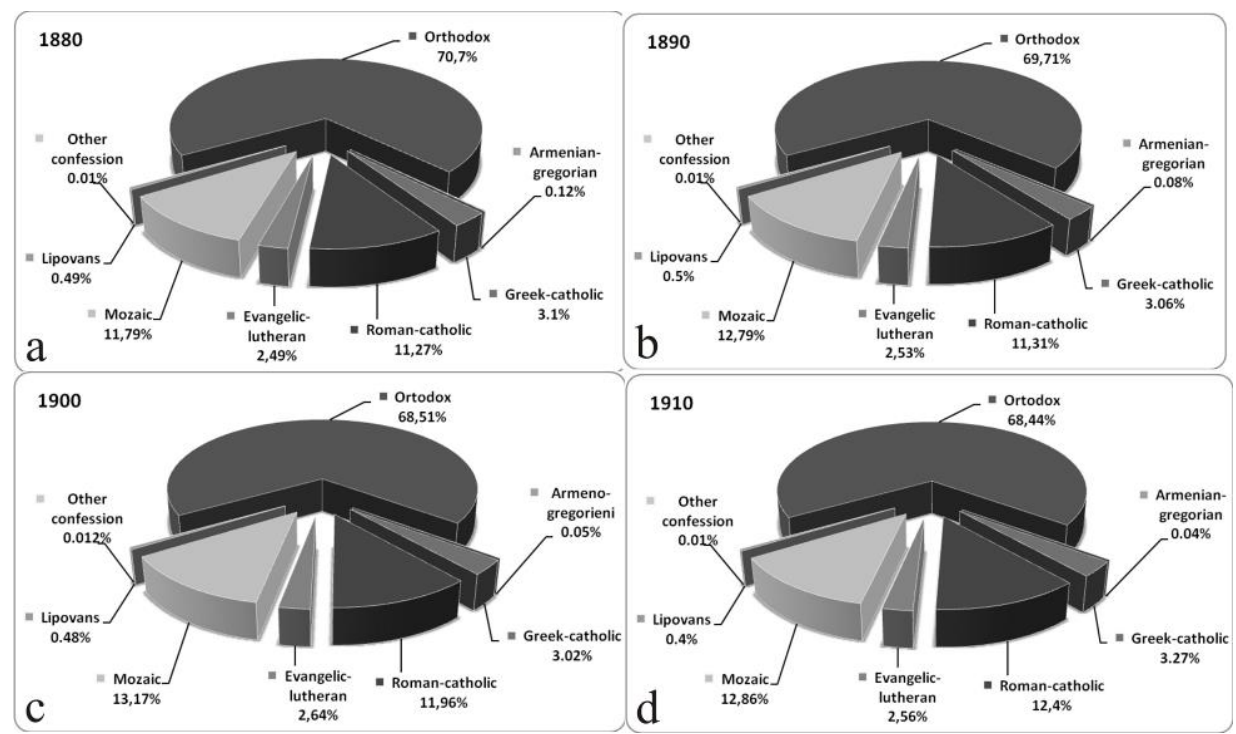

Figure 5. The confessional structure of the population in Bucovina

Table 3. The evolution of the confessional structure of the populatian of Bucovina (\%)

\begin{tabular}{|c|c|c|c|c|}
\hline Year & $\mathbf{1 8 8 0}$ & $\mathbf{1 8 9 0}$ & $\mathbf{1 9 0 0}$ & $\mathbf{1 9 1 0}$ \\
\hline Orthodox & 70.7 & 69.71 & 68.51 & 68.44 \\
\hline Armenian-gregorian & 0.12 & 0.08 & 0.05 & 0.04 \\
\hline Greek-catholic & 3.1 & 3.06 & 3.20 & 3.27 \\
\hline Roman-catholic & 11.27 & 11.31 & 11.92 & 12.40 \\
\hline Evangelic-lutheran & 2.49 & 2.53 & 2.64 & 2.56 \\
\hline Mosaic & 11.79 & 12.79 & 13.17 & 12.86 \\
\hline Lipovans & 0.49 & 0.50 & 0.48 & 0.40 \\
\hline Other confessions & 0.01 & 0.01 & 0.012 & 0.01 \\
\hline Total & $\mathbf{1 0 0}$ & $\mathbf{1 0 0}$ & $\mathbf{1 0 0}$ & $\mathbf{1 0 0}$ \\
\hline
\end{tabular}

Source: Mitteilungen des statistischen

The results of the 1910 census are reflected differently from a cartographical point of view by the leading representatives of both the Romanian and Ukrainian communities (Table 3) [13]. Thus, on the ethnographic map of Bucovina, composed by the Romanian historian I. Nistor we find highlighted 8 ethnic groups (Fig. 2) while on the map composed by A. Zukovsky (Fig. 3) we find highlighted only 6 groups, the Hutsuls and Lipovans being absent because they were assigned to the Ukrainians. During this time, the confessional structure of the population of Bucovina modifies considerably (Fig. 4, 5).

\section{CONCLUSIONS}

Presently, Bucovina is divided between two states, its south forming the largest part of Suceava County in Romania, its north being included in the Czernowitz region of Ukraine. From a cultural standpoint, because its inclusion into the Austrian state, Bucovina, between 1775 - 1918 was part of the area of influence of the central European culture, slightly faded in the years between 1918 - 1944, and in the period between 1944 - 1984, because of the Soviet occupation and the communist regime completely absent. After 1989, both the Czernowitz region and Suceava County became gradually and partially reconnected with the central-European cultural area, the process continuing even today. 
Bucovina represents a unique region within Romania from several points of view. Firstly, it's the only region of the historical Moldova that was a part of the central-European cultural area.

Secondly, Bucovina became a model of peaceful co-existence, being inhabited by 11 ethnic groups which were themselves part of 9 religious confessions. Bucovina became an example of inter-ethnic collaboration, giving birth to the famous expression "Homo bucovinensis", the prototype of the tolerant individual, one that speaks at least two languages, and which offers a model of inter-ethnic cohabitation.

Thirdly, Bucovina is the only region of Romania which still constantly maintains the attention of foreign academic circles, even though no significant number of German or Hungarian ethnics still lives here, compared to Transylvania. The focus of Bucovina towards the models of central-European culture and civilization was accomplished mainly through the influence of the Germans. The first German colonists were mostly farmers and craftsmen, a large number of officials arriving soon after. The Bucovinean Germans founded many cultural societies, which continued their activity during the interwar period. A significant part of the Bucovinean Germans emigrated in Germany during the period of the Second World War. Nowadays, the Germans have a reduced demographic share.

\section{ACKNOWLEDGMENTS}

This study was supported by the Partnership in Priority Domains project PN-II-PTPCCA2013-4-2234 no. 314/2014 of the Romanian National Research Council, Nondestructive approaches to complex archaeological sites. An integrated applied research model for cultural heritage management—arheoinvest.uaic.ro/research/prospect.

\section{REFERENCES}

[1] Pintescu F. Bucovina, zona de convergenta etnica si spirituala. ROCSIR, Revista Romana de Studii Culturale (Internet), nr.1, an 2000, pp. 9-16.

[2] Beck E. Bujowina. Land zwischen Orient und Okzident. Pannonia-Verlag, Freilassing, 1963.

[3] Abutnaritei I. Monitorul de Dorna. 23 ianuarie 2013, 2013.

[4] Ungureanu C. Bucovina in perioada stapanirii austriece 1774-1919, 2003.

[5] Zieglauer F. Geschichtliche Bilder aus der Bukowina zur Zeit der österreichischen Militärverwaltung. Bide I-XII, Czernowitz, 1893-1908, 1909, pp.13-30.

[6] Polek J. Ortschaftsverzeichnis der Bukowina aus dem jahre 1775.In:JBLM. - 1/1893, p.39.

[7] Klun V.F. Statistik von Oesterreich-Ungam. Wien, 1876.

[8] Werenka D. Topographie der Bukowina zur Zeit ihrer Erwerbung durch Österreich (1774-1785). Czernowitz, 1895, pp.9-124.

[9] Roman L. Locuitorii Bucovinei (Les abitant de la Bucovine). 1774-1803. In: Revista istorica, serie noua, tom VI, nr.9-10, 1995, pp.807-824.

[10] Purici S. Colonozari si imigrari in Bucovina intre anii 1775-1848. Analele Bucovinei, an II, 2, 1995, pp.357-375.

[11] Ost G. Ostafi Etnic si economic in Bucovina si Suceava. Anuarul Muzeului Judetean al Bucovinei, XXIV-XXV, 1997-1998, Suceava, 2000, pp.217-229.

[12] Toroutiu I.E. Populatia si clasele sociale din Bucovina. Bucuresti, 1916, pp.34-38.

[13] Die Ergebnisse der Volkszählung vom 31. Dezember 1910 im Herzogtume Bukowina, în Mitteilungen des statistischen Landesamtes des Herzogtums Bukowina, XVII Heft, Czernowitz 1913, pp.54-55. 